Yrd. Doç. Dr.

Hasan IŞIK
Ankara Yıldırım Beyazıt Üniversitesi insan ve Toplum Bilimleri Fakültesi

Tarih Bölümü Öğretim Üyesi, hasantarih@yahoo.com
Dr. Öğrencisi Ahmet DOĞAN
Ankara Yıldırım Beyazıt Üniversitesi Insan ve Toplum

Bilimleri Fakültesi Tarih Bölümü Doktora Öğrencisi, adogan1299@hotmail.comtr

\title{
Genel Türk Tarihinin Kaynaklarından Süreli Yayınlara Bir Örnek: Kırım Mecmuası
}

\section{A Reference Source of General Turkish History from Periodicals: The Journal of Crimea}

\section{ÖZET}

Genel Türk Tarihi'nin birinci el ve ikinci el kaynaklarının yanında bu kaynakları içinde barındıran süreli yayınlardan çıkan birçok dergi yer almaktadır. Özellikle yaklaşık son asrı kapsayan bu dergilerin birçoğu bu alana önemli katkılar yapmıștır. Türk Yurdu, Türkiyat Mecmuası, İstanbul Üniversitesi Edebiyat Fakültesi Tarih Dergisi, Türk Kültürü, Bilig, Belleten ilkgöze çarpan dergilerdendir. Bunların yanında yayınlandığı dönemlerde Türk tarihine büyük hizmetler vermiş fakat kısa süre sonra yayın hayatından çekilmiş dergilerde bulunmaktadır. Bunlardan biriside 2 Mayıs 1918 ile 15 Mayıs 1919 tarihleri arasında yirmi üç sayı olarak neşredilen, Kırım ve Türk dünyasıyla alakalı ilmî, edebî, dinî, ictimaî ve tarihî mevzuları işleyen, Kırım'la ilgili her türlü olayı Türk dünyasına ve Avrupa'ya hemen duyurmaya çalışan Kırım Mecmuası'dır. Bu dergi Kırım Ahali Cumhuriyeti'nin Bolşevikler tarafından ortadan kaldırılmasından sonra İstanbul'da Kırım'ın bağımsızlığını savunan bir dergidir. Dergide yer alan ve genel Türk tarihi alanında birinci el kaynak özelliği taşıyan birçok görsel, harita vb. önemli bir kaynak hazinesidir. Bugün Kırım'ın tekrar Rusya tarafından ilhakının gündemde olduğu bir zamanda bu derginin gündeme getirilmesinin ve tanıtılmasının önemli olduğu da düşünülmektedir. Çalışmada, bu derginin yayınlanmasına sebep olan olaylar silsilesine, bu 
derginin yayınlandığı sürede derginin oluşturduğu önemli etkiye, derginin önemli yazarlarına, derginin genel Türk tarihi içerisinde sahip olduğu öneme, yayınlanan 23 sayının içeriğine yer verilecektir. Bu şekilde konu ve dönemle ilgili çalışma yapacak araștırmacıların bu dergiye dikkatlerini çekmek ve böylece derginin içeriğinin ilgili araștırmacılarca kullanılmasını sağlamak amaçlanmaktadır.

Anahtar Kelimeler: Kırım, Mecmua, Genel Türk tarihi, Kaynak, Türkçülük

\section{ABSTRACT}

Besides primary and secondary source materials of General Turkish History, numerous journals that come out in periodicals covering all these sources are also available. Many of these journals including particularly upcoming last century have contributed to this field of study. Turkish Land, Journal of Turkish Studies, Istanbul University History Journal of the Faculty of Arts, Turkish Culture, Bilig and Belleten could be considered as the prominent ones. There are still many other journals that shed light on Turkish History during the publication of those and stopped getting published soon afterwards. The Journal of Crimea, which was published in 23 issues from 2 May 1918 to 15 May 1919, is a great source in terms of handling scientific, literary, religious, social and historical affairs concerning Crimea and Turkey and also trying to proclaim all these to Turkey and Europe at once. The Journal of Crimea defended the independence of Crimea after Bolshevik's annexation of The Crimean People's Republic. The journal is of vital importance in that many of the visuals in the journal have the characteristics of being primary source in the field of General Turkish History and maps. At the time when the annexation of Crimea by Russian is on the agenda, it's also considered crucial to bring up and revive this journal. This study will give a wide coverage to the sequence of events that paved the way for publishing the journal, its prominent authors and profound impact during the publication period, the significance that the journal has in the field of General Turkish History and the context of 23 issues. Hence, it is aimed at drawing the attention of the researchers, scholars and analysts who will study on this issue and this period so that the context of the journal can be employed as a source by the related researchers.

Key Words: Crimea, Journal, General Turkish History, Reference, Turkism

\section{Giriş}

Kırım, batı ve güneyden Karadeniz, doğu ve kuzeyden Azak ve en derin yeri bir buçuk metreyi geçmeyen sı̆̆ denizlerle kuşatılmış olup; tabiatça bir ada hususiyetini taşıdığından, yerli halkı tarafından yeşil ada ${ }^{1}$ olarak tanımlanmaktadır. Jeopolitik konumu itibarıyla da Osmanlı Devleti padişahı Fatih'in dikkatini çekmiş ve 1475 yılında Gedik Ahmet Paşa komutasındaki donanmayla Cenevizlilerin elinde esir bulunan Mengli Giray Han hapisten çıkartılarak Kırım Hanı yapılmış ve Kırım’da Osmanlı egemenliği başlamıştır.² Osmanlı

1 Şevki Bektöre, “Kırım İçün”, Kırım Mecmuası, nr. 1, İstanbul 2 Mayıs 1334/1918, s. 2.

2 Mirza Bala, "Kırım", İA., C.6, s.747 
egemenliği altında uzun bir müddet rahat bir şekilde yaşayan Kırımlılar; ilim, edebiyat ve kültür bakımından çok ilerlemişlerdir.

Osmanlı Devleti'nin zayıflaması ve Rus Çarlığı'nın güçlenmesiyle birlikte Kafkasya'daki güç dengeleri de değişmeye başlamıştı. Karlofça Anlaşması'ndan sonra Osmanlı Devleti'nin gerilemesine paralel olarak sıcak denizlere açılmak isteyen Rusya, bu amaçla ilk adım olan Kırım yarımadasını ele geçirmek için teşebbüste bulunmuştur. Rusya, Osmanlı ve Kırım ordularını yenilgiye uğratmış, Küçük Kaynarca ve Yaş anlaşmalarıyla Kırım’ı Osmanlılardan ayırmıştı. Nihayetinde Rusya, 8 Nisan 1783 tarihinde Çariçe II. Katerina'nın manifestosuyla Kırım'ı ilhak etti. Çariçe'nin; "biz gerek kendi namımıza ve gerekse halkımız namına Kırımlılar'ın canlarına, mallarına, mülklerine, dinlerine hürmet edeceğiz ve bunun hiçbir vechile ref've ilga edilmeyeceğini resmî ve kudsî olarak taahhüd ederiz" şeklindeki manifestosu okunarak, Kırım resmen işgal edilmişti ${ }^{3}$. Fakat Çariçe II.Katerina'nın manifestosunda belirttiği hak ve özgürlük taahhüdü sözde kalmıştır. 1783 yılındaki Rus ilhakı esnasında savaş esirleri hariç tutulacak olursa, hiçbir Rus sakini bulunmayan Kırım, Ruslarda hayranlık uyandırmıştı . Bu sebeple Rusya, Kırım'ın yerli halkı üzerinde tamamen baskıya dayalı bir kolonizasyona girișmişti. Bir müşahit olarak İngiliz seyyah Klark, Kırım-Kefe'de gördüklerini şöyle anlatır: 'Rus askerleri minareleri deviriyor, camileri, umumi çeşmeleri yıkıyor, mezarlıkta kabir taşlarını kırıyorlar ${ }^{5}$. $\mathrm{Bu}$ baskı ve asimilasyon sonucu pek çok Kırımlı vatanlarını terk ederek ak topraklar olarak niteledikleri Anadolu'ya göç etmişlerdir.

Kırım'ın Ruslar tarafından işgali ve kolonizasyon siyaseti nedeniyle birçok Kırımlının öz vatanlarından sürülmesine rağmen, bazıları kendi vatanlarında yetim kalmak pahasına yurtlarını terk etmemiş ve tekrar eski günlerine dönebilmek için firsat kollamışlardı. Bu gayeyle de ilkin geniş bir toplumsal reform hareketine girişilmiş ve bu hareketin önderliğini de İsmail Gaspıralı yapmıștır 6 . İsmail Gaspıralı'nın önderlik ettiği bu reform hareketi meyvesini özellikle 1905-1917 yılları arasındaki dönemde vermiştir. Bu dönem; yüzyıllardır esaret ve cehaletin karanlığında kalmış, asimilasyon ve kolonizasyon uygulamalarıyla sindirilmiş bir milletin siyasî, millî ve kültürel uyanıșının bașlangıcıdır. Bolșevik ihtilalinin de etkisiyle ortaya çıkan karışıklıktan istifade eden Kırımlılar 1917 yılında "Kırım Ahali Cumhuriyeti"ni kurmuşlardır. Fakat çok geçmeden toparlanan (Rusya) Bolşevikler ileri harekâtta bulunmuş ve Kırım millî ordusunu yenerek Akmescid'e girmişlerdi. Derhal Kırım Millî hükümeti üyeleri ve birçok Kırımlı gözaltına alınmış, yalnızca Cafer Seydahmet Efendi kaçarak kurtulabilmişti. Tutuklananlar arasında bulunan Devlet Başkanı Çelebi Cihan Efendi ise, Sivastopol'e götürülerek kurşuna dizilmiş ve naşı Karadeniz'e atılmıştı ${ }^{7}$.

Kırım bağımsız devletinin yıkılmasından sonra Osmanlı ülkesine gelmeyi başaran

3 Selim Ortay, Kırım'ın İstiklal Davası, Köstence Mayıs 1939, s. 21.

4 Hakan Kırımlı, Kırım Tatarları'nda Millî Kimlik ve Millî Faaliyetleri (1905-1916), Ankara 1996, s. 9.

5 Selim Ortay, age, s. 22.

6 Osman Kemal Hatif, Gök Bayrak Altında Millî Faâliyet, İstanbul 1334 (1918), s. 11-12; Necip Hablemitoğlu, Çarlık Rusyasında Türk Kongreleri (1905-1917), Ankara 1997, s. 27-28; Nadir Devlet, 1917 Ekim İhtilali ve Türk-Tatar Meclisi (İç Rusya ve Sibirya Müslüman Türk Tatarlarının Millet Meclisi-1917-1919), İstanbul 1998, s. 45-46; İhsan Ilgar, Rusya'da Birinci Müslüman Kongresi, İstanbul 1988, s. 21-22.

7 Osman Kemal Hatif, “Çelebi Cihan Efendi Merhum”, Kırım Mecmuası, nr. 1, İstanbul 2 Mayıs 1334/1918, s. 12-14; Aynı Müellif, "Kırım’da Bolşevik İstilâsı Târihinden-I”, Kırım Mecmuası, nr. 9, İstanbul 22 Ağustos 1334/1918, s. 161-164; 
münevver Kırımlılar, kendilerinden önce ak topraklara göçen Kırımlılarla birlikte vatanlarının bağımsızlığı için bu kez İstanbul'da mücadele etmeye başlamışlardır. Özellikle dernekler ve basın yoluyla Kırım'ın Türklüğünü savunmaya çalışmışlardır. Söz konusu faaliyetlerin en mühimi, bağımsız Kırım’ın propagandasını yapan “Kırım Mecmuası” idi. Bu çalışmada; Kafkasya Türk tarihinin ve genel Türk tarihinin kaynaklarından olan ve alanla ilgili birçok birinci el kaynağı barındıran Kırım Mecmuası ve mecmuada işlenen ana konular hakkında bilgi vereceğiz.

\section{Genel Türk Tarihinin Kaynakları Açısından Süreli Yayınlar}

Genel Türk tarihi Avrasya coğrafyası ağırlıklı olarak Osmanlı ve Selçuklu dışındaki Türk tarihi olarak anlaşılmaktadır. Bölgesel olarak Avrasya coğrafyasındaki Türklerin tarihidir ${ }^{8}$. Bu tarihi içeren alan Öntürklerden, Hunlardan bugüne kadar birçok devleti kapsayan bir alandır. Bilinen tarihin hemen hemen her devrinde Türkler var olmuşlardır. Türklerin Orta Asya'dan başlayan tarihi maceraları, benimsedikleri kültür ve hayat tarzı sebebiyle anayurdun dışına taşmış ve bu millet beş kıtada önemli izler bırakmıștır. ${ }^{9}$ Bu kadar geniş bir içeriğe sahip olan alanın sözlü, yazılı ve arkeolojik gibi üç ana başlıkta toplayabileceğimiz zengin bir kaynağı oluşmuştur.

Alanın en önemli kaynaklarından olan yazılı kaynaklar denilince de akla kitabeler, sözlükler, siyaset-nameler, coğrafya eserleri, genel ve özel tarihler ve ayrıca kültürümüz için önemli olan fal kitapları, dini metinler, mektuplar ve yarlıklar gelir ${ }^{10}$. Birinci elden öneme sahip olan bu kaynakların yanında dikkat çeken önemli bir kaynak türü de yazılı kaynaklar başlığı altında değineceğimiz içerisinde birçok birinci ve ikinci el kaynağı barındıran süreli yayınlardır. Bu alanda özellikle uzunca bir birikime sahip olan ve genel Türk tarihi alanının içeriği ile ilgili ağırlıkta yayın yapan birçok dergi dikkat çekmektedir. Bu dergilerden bazılarının ömrü uzun, bazıların ki kısa sürmüş ve bazıları da unutulup gitmiştir. Genel Türk tarihi'nin yukarıda belirtilen kapsamı göz önüne alındığında Kırım ve Kırım’ın tarihinin bu alan için ilişkisi ve önemi fark edilecektir. Bu çerçevede Kırım ile ilişkili yayınlanan ve ömrü kısa süren yirmi üç sayı olarak yayınlanan "Kırım Mecmuası" alan itibari ile önemli bir kaynak hüviyeti göstermektedir.

\section{Kırım Mecmuası'nın Doğuşu ve Önemi}

Eski yazıyla neşr edilen Kırım Mecmuası, Kırımlılar Cemiyet-i Hayriyyesi'nin de kurucularından olan Kırımlı Süleyman Sudi Bey tarafından yayımlanmıştır. Mecmua, on beş günde bir yayımlanmak üzere neşir hayatına başlamış ve 2 Mayıs 1334/1918-15 Mayıs 1335/1919 tarihleri arasında yirmi üç sayı olarak neşredilmiştir. Mecmuada, Kırım ve Türk dünyasıyla alakalı ilmî, edebî, dinî, ictimaî ve tarihî mevzular işlenmiş ve Kırım’la ilgili her türlü olay Türk dünyası ve Avrupa'ya hemen duyurulmaya çalışılmıştı. Bu bakımdan Kırım Mecmuası, Kırım Millî Hükûmeti’nin resmî gazetesi olan Millet Gazetesi’nin yerini almış ve

8 Ahmet Taşağıl, "Genel Türk Tarihi”, Tarih İçin Metodoloji, (Ed. A. Şimşek), Pegem Akademi Yayınları, Ankara 2016, s. 62.

9 Varis Çakan, Orta Asya Türk Tarihinin Kaynakları, Binyıl Yayınları, Ankara 2009, s.16.

10 Saadettin Gömeç, İslam Öncesi Türk Tarihinin Kaynakları Üzerine, Ankara Üniversitesi Dil ve Tarih-Coğrafya Fakültesi Tarih Bölümü Tarih Araştırmaları Dergisi, Cilt. 20, Sayı 31, Ankara 2002, s. 64 
Kırım'la alakalı her türlü vak’aya çok güçlü bir reaksiyon göstermiştir.

İstanbul'da Babıali'de Orhaniye Matbaası'nda basılan mecmua, genellikle Osmanlı ülkesi içinde ve ecnebi memleketlerde abonelik yoluyla dağıtılmaktadır. Fiyatı 5 kuruştur. Eski sayıları 10 kuruştur. Abonelik olarak Osmanlı topraklarında 120 kuruş, ecnebi memleketlerde ise 30 franktır. Mecmuanın dış ve iç kapaklarına muhtelif reklamlar alınarak gelir elde edildiği anlaşılmaktadır. Söz konusu reklamlar arasında; diş doktorundan kunduracıya, her türlü ilaçlara, kitapçıdan yeni çıkan kitaplara, dergilerin o haftaki sayılarına, özel dersler veren muallim ve muallimelere, aşçılara, kiralık ve satılık evlerle emlaklara, çay ve yağ gibi gıda maddelerine kadar, günlük hayatın hemen her alanında lüzumlu olan şeylerin reklamına yer verilmiştir.

Mecmuanın sahibi Süleyman Sudi Bey, aynı zamanda bilinen bir kitapçıdır. Kitabhane-i Sudi'nin sahibi olarak, birçok kitabın ilk baskısını hemen okuyucularına duyurmuş, bunların bazılarını kendisi basmış ve yeni çıkan mecmuaların tanıtımını yapmak suretiyle, Türk kültür hayatına önemli hizmetlerde bulunmuștur. Söz konusu dergi ve kitaplar arasında; felsefe, tarih, kadın, mizah, adab-ı muaşeret vb. konulu birçok eserin ilanı yapılmıştır.

Mecmuanın gayesi, mecmuanın ilk sayısında neşredilen bir makalede açıkça ortaya konarak şöyle denmektedir:

"Kırım Mecmuası șanlı Osmanlı ve müttefikordular silahlarının (BüyükTuran) mefkûresine müsaid olarak ihdas eylemiş olduğu vaziyetin mevlîdidir. Şimdiye kadar Osmanlı Türkleri, Rusya'da, Kafkasya'da, Türkistan'da, Sibirya'da, Çin'de, Macaristan'da, birçok arkadaşlarının bulunduğunu biliyor ve fakat Moskof Çarlığı'nın, şarkı asırlarca müddet tazyik-i maddi ve maneviyatı altında bulundurmuş olan siyaset-i mensumesi hasebiyle akvam-ı mezkure ile harsi, iktisadi, ve ameli münasebetini tekamül ettiremiyordu... Turan irkına mensub milletlerin yekdigerine takarrüb hususundaki temayülünün şiddetine, lisan hususunda görülmekte olan tekâmül en büyük bir delil teşkil eder. Kırım Mecmuası bu temâyüle hizmet edecek ve Osmanlı Türkleriyle Rusya Müslümanları arasında bu râbıta-yı ilmiyye ve harsiyye tesîsine çalışacaktır... ,11

Türk dünyası üzerinde gezinen gaflet bulutunun yok edilmesi, Osmanlı Devleti'yle Rusya Müslümanları arasında birliği sağlamak, Rusya'nın takip ettiği bölücülük ve kabilecilik politikasının önüne geçmek, Türk milletini aydınlatmak ve Gaspıralı İsmail'in, "dilde, fikirde, işte birlik" düsturu doğrultusunda Turan ülkeleri arasındaki birliği temin etmek ve Kırım’ın Bolşevikler tarafından işgalini protesto ederek, her fırsatta bunu dile getirmek mecmuanın amacıdır. Mecmua'da Bolşevikler tarafından yapılan işgal şu şekilde duyurulmuştur;

“Bolşevik çetelerinin Alma boyundan Akmescid'e gelmesi üzerine, şehirde yağma ve kıtal başladı. Her tarafa dehşet salmak için bolşevikler hiçbir hedef gözetmeyerek top, tüfenk ve mitralyoz ateşine devam ediyorlardı. Her tarafa yayılmış olan matros (bahriye) çeteleri, masum ve bi-günah birçok ahaliyi kurşuna diziyor; aynı çetelerden bir kısmı Tatar parlamentosunun ictimagâhı olan (Dvaryanskoe Sabranie) binasına gelerek ölüm tehdidi tahtında olarak oradaki mebuslardan eslihanın kendilerine teslim olunmasını talep

11 İsimsiz, “Tutduğumuz Yol”, Kırım Mecmuası, nr. 1, İstanbul 2 Mayıs 1334/1918, s. 1. 
ediyorlardı..."12

Kırım Mecmuası'nın bilhassa Kırımlı muhacirlere yaptığı hizmetler, mecmuanın onlar tarafından önemli oranda desteklenmesine yol açmıştır. Mesela, Eskişehir'deki Çiftçi Bankası, mecmuanın finansında önemli bir yere sahiptir. Banka ve mecmua arasında kurulan iyi ilişkiler ticarete de yansımıștır. Banka, Kırımlı muhacirlerin parasını kendi bankalarına yatırmalarını sağlamak için mecmuaya ilanlar vererek finansal anlamda mecmuayı desteklemiştir. ${ }^{13}$ Kafkasya Göçmenleri iğneden ipliğe kadar derginin finansında çok önemli bir yere sahiptirler. $\mathrm{Bu}$ da, mecmuanın işlevini büyük oranda yerine getirdiğini göstermektedir ${ }^{14}$.

\section{Kırım Mecmuası'nın Yazarları ve İçeriği}

Mecmuada genellikle fikir yazısı, tarih, edebiyat ve folklor, tiyatro ve şiir türü konuların yayınlandığı görülmektedir. Bunların yanında özellikle Kırım hükümdarları, Kırımın coğrafi özellikleri de yoğun bir şekilde işlenmiştir. Yazıların büyük çoğunluğu İstanbul lehçesiyle kaleme alınırken, bir kısmı da Tatar lehçesiyle yazılmış ve söz konusu eserlerin sonuna lügatçe ilave edilmiştir.

Mecmuanın değişmez yazarları, Kırım’ın aydınlarıdır. Derginin yazarlarının azımsanamayacak bir kısmı Kırım bağımsız devletinin propagandistidir. Bunların bazısı Bolşevik istilası sebebiyle Kırım'dan göçmüş veya daha evvelki göçler sırasında Anadolu'ya gelmiştir. Mesela, Osman Kemal Hatif, Fevzi Altok, Osman Akçokraklı, Mahmud Mesud, Şevki Bektöre, Abdülhalim Hilmi, Seyyid Celil Hattatof, Muallim Hüsameddin, Cafer Seyyid Ahmed, Fahreddin Tonguç, Çubukçuzade Safveti Kemal, Raşid Așki Çorabatur, Ayas İshaki, Çobanzade Bekir Sıdkı gibi. Diğer taraftan Ömer Seyfeddin, Hamdullah Subhi, Hüseyin Cahid, Habil Adem, Bursalı Mehmet Tahir gibi bazı Osmanlı aydınları da yazarlar arasında bulunmaktadır.

Mecmuada işlenen konulardan öne çlkanlara değinilecek olursa; dikkat çekenlerden birisi din konusudur. Mecmuada dinin bütünleştirici rolü üzerinde durulmuş ve milliyet prensipleriyle çatışmadığı üzerinde fikir birliğine varılmış görünmektedir. Mecmuada birlik ve beraberlik mevzuları işlenirken, dinin bütünleștirici hususiyeti işlenmiş ve İslamiyet'in gericilik, softalık, cehalet ve ilkellik olmadığı izah edilmiştir. Böylece, çatışan güçler yerine müttefik güçler oluşturulmaya çalıșılmıștır. Diğer taraftan, yukarıda da değinildiği gibi, İslamiyet'in milliyetçilikle kavgalı olmadığına ilişkin epeyce yazı yazılmış ve Türk milliyetçiliğinin kaçınılmaz bir gerçek olduğu "Dinleriyle dilleri bir olan Türkler de bir millettir. Türk milletinin dini Íslam'dır, dili Türkçe'dir.” şeklinde ifade edilerek önemle vurgulanmıştır ${ }^{15}$.

12 Osman Kemal Hatif, “Kırım'da Bolşevik İstilası Tarihinden I', Kırım Mecmuası, nr. 9, İstanbul 22 Ağustos 1334/1918, s. 161-164.

13 İlan için bkz. Kırım Mecmuası, nr.21, ön sayfa ilanları

14 Raşid Aşkî Çorabatur, “Eskişehir”, Kırım Mecmuası, nr. 20, İstanbul 6 Mart 1335/1919, s. 351-353, Ahmet Doğan, Kırım Mecmuası 1-23 sayılar(Fihrist ve Metinler), Basılmamış Yüksek Lisans Tezi, Atatürk Üniversitesi Sosyal Bilimler Enstitüsü, Erzurum 2000, s. 8-10

15 Ömer Seyfeddin, "Büyük Türklüğü Parçalayanlar Kimlerdir?”, Kırım Mecmuası, nr. 1, İstanbul 2 Mayıs 1334, s. 3-5; Bu konulardaki birkaç makale için bkz. Çubukçuzade Safveti Kemal, "Türklük-Tatarlık-I-II-III", Kırım Mecmuası nr. 2, İstanbul 16 Mayıs 1334, s. 27-28; Kırım Mecmuası, nr. 5, İstanbul 27 Haziran 1334, s. 88; Kırım Mecmuası , nr. 7, İstanbul 25 Temmuz 1334, s. 125-126; Halim Sabit, "Türk Birliği Yolunda", Kırım Mecmuası, nr. 2, İstanbul 16 Mayıs 1334, s. 28, 33-34; Mahmud Mesud, "Milliyet Prensipleri Hakiki Müslümanlara Kabil-i Tatbik midir?”, Kırım Mecmuası, nr. 16, İstanbul 12 Kanunievvel 1334, s. $284-285$. 
Milliyetçiliğin devamı ve bir parçası olarak, mecmuada işlenen mühim hususlardan bir diğeri de Türklük ve Tatarlık meselesidir. Mecmuadaki yazılara bakılırsa Tatarlık, Rusların bir aldatmacası olup, Türk birliğini parçalamak için Türkler arasına kasıtla sokulmuştur. Ruslar, Türklerin Tatar, Kırgız, Kazak, Özbek gibi boy ve kabile isimlerini öne çıkarmış, hatta Türkçenin lehçe ve şivelerini ayrı dillermiş gibi göstererek, Türkler arasında boy milliyetçiliğini kışkırtmıştır. Muharrirlerin önemli bir kısmı bu aldatmaca karşısında, Gaspıralı'nın yolunu izlemiş ve bunun gerçek olmadığını ısrarla söylemiş̧tir. Kırım Mecmuası yazarları, Kırım veya bir başka Türk ülkesinin bağımsızlı̆̆ının yolunu, Türk ve Müslümanların birliğinde görmektedir. Mecmuada Türklük ve Tatarlık kavramları kucaklaştırılmaya çalışılmış, mazideki parlak günlerin ancak birlik ve beraberlikle gerçekleşebileceği belirtilerek, düşmanların ise Türkleri parçalamak ve yok etmek için her şeyi yapacağı üzerinde durulmuştur ${ }^{16}$. TürklükTatarlık konusunda Çubukçuzade Safveti Kemal bakış açısını mecmuada şu şekilde ifade etmiştir.

"Biribirinin etini budunu yolmak, mevcudiyetini kemirmek için var kuvvetiyle uğraşan iki din kardeșinin ötede bu gibi mesaili külliyen kale bile almak lüzum ve mecburiyetini terakkiyat-ı asriyye ve medeniyyeye muhalif görerek, elbirliğiyle itilaya doğru hatve-endaz olanların mesai-i meşkûrelerini görememeleri ve bundan da: Evvelkilerin tedenni ve inhitatına mukabil, sonrakilerin her cihetden cihan-1 terakkiyatına, cihan-1 mamuriyyet ve inkişafına hakim olup kalmaları neticesinin çıkması kadar tabii bir şey yokdur ve olamaz. Çünkü, birinciler "sensin bensin" ile meşgul iken, diğerleri terakki ve itila yolunda koşmakda ve hatta o yolda can vermekdedirler."17

Mecmuada Türk Dünyasının birlikteliğinin önemi üzerinde de durulmuş ve bunun her alanda olduğu gibi İsmail Gaspıralı'nın 'Dilde, fikirde, işte birlik' fikrine sıkı sıkıya bağlı kalınmasıyla gerçekleştirilebileceği belirtilmiştir. Mecmua, İstanbul Türkçesiyle yayınlanmış olup Türk Dünyasıyla ilgili yapılacak bütün yayınların da İstanbul Türkçesiyle yayınlanması gerektiğini şiddetle savunmuştur ${ }^{18}$. Bu konu hakkında mecmuada çok fazla yayın bulunmakla birlikte özellikle Ömer Seyfettin'in “Büyük Türklüğü Parçalayanlar Kimlerdir?”konulu yazısı dikkat çekmektedir.

"Dilde, fikirde, işte birlik" şiârıyla bütün Türk milletinin birleşmesine çalışan İsmâil Gasprinski Efendi de vaktiyle Turan'da anlaşılamamıştı. Şimal Türkleri “Nur” gazetesiyle “Biz Tatarız!" diye bu büyük adama itiraz ediyorlar, onun millî hakikatini idrak edemiyorlardı. Zaman geçti. Hakikat ilerledi, bu hakikati tutmak isteyen el kırıldı. Şimdi bütün Türkler bunu bilmelidir:

16 Çubukçuzade Safveti Kemal, "Türklük-Tatarlık-I-II-III”, Kırım Mecmuası, nr. 2, İstanbul 16 Mayıs 1334 , s. 27-28; Kırım Mecmuası, nr. 5, İstanbul 27 Haziran 1334, s. 88; Kırım Mecmuası, nr. 7, İstanbul 25 Temmuz 1334, s. 125-126; Halim Sabit, "Türk Birliği Yolunda”, Kırım Mecmuası, nr. 2, İstanbul 16 Mayıs 1334, s. 28, 33-34;

17 Çubukçuzade Safveti Kemal,’Türklük Tatarlık III”, Kırım Mecmuası, nr.7, İstanbul 25 Temmuz 1334, s.125-126

18 Abdülmecid Şamil, “Büyük (Gaspirinski’nin) tezkirnamı”, Kırım Mecmuası, nr.1, İstanbul 2 Mayıs 1334/1918, s. 6-7, Safveti Kemal, "Dilde,fikirde,işde birlik”, Kırım Mecmuası, nr.3, İstanbul 30 Mayıs 1334/1918, s.43.44, Galatasaray Sultanisi Muallimi Nüzhet Haşim, "Bugünkü Türkçülükte Lisan Telakkisi”, Kırım Mecmuası, nr.4, İstanbul 13 Haziran 1334/1918, s. 75-76, Muallim Hüsameddin, "Kırımda Lisan-1 Resmi Meselesi”, Kırım Mecmuası, nr.9, İstanbul 22Ağustos 1334/1918,s. 167. 
1- Dünyada (dini, dili bir) büyük bir Türk milleti vardır.

2- Ayrı ayrı (Türk devletleri) olabilir. Kırım, Kafkasya, Buhara, Türkistan ve ilh... Fakat ayrı ayrı Türk milletleri olamaz!

3- Ayrı ayrı (Türk lehçeleri) olabilir. Kastamonu, Erzurum, Azerbaycan, Bakü, Kazan, Hokand, Kaşgar ve ilh... lehçeleri gibi! Fakat ayrı ayrı Türkçe olmaz. Umumi Türkçe birdir. 0 da en büyük Türklük merkezinin, hakanın, halifenin oturduğu, Türk darülfünûnunun bulunduğu yerin lîsânıdır! Yani (İstanbul Türkçesidir!) ${ }^{19 ”}$

Mecmuada üzerinde durulan mühim mevzulardan biri de kadınlardır. Yazarlar, tarihteki Türk devletlerinde aile yapısı ve günlük yaşantı üzerinde durarak, bunlar arasında kadının rolünü tespite çalışmışlardır. Her alanda olduğu gibi burada da Gaspıralı'nın fikirleri yol gösterici durumdadır. Söz konusu fikirler, kadınların erkeklerle eşit haklara sahip olması gerektiği yolundadır. Özellikle 1917 Kırım Kurultay’ında bazı kadınların önemli görevlere getirilmesi mecmuada birçok yazar tarafından dile getirilmiş, Türk toplumunda eskiden beri kadınlara verilen değer üzerinde durulmuştur. Ancak kadınların hem İslam dünyasında hem de Türkler arasında toplumsal işlev bakımından geriye itildiği de tespit edilmektedir. Diğer taraftan, 1905 ihtilaliyle rey hakkı tanınan kadınların, Rusya içindeki Kırım'da oy kullanmalarını teșvik bakımından da, konuya ayrı bir ehemmiyet verilmiş görünmektedir ${ }^{20}$. Nitekim 26 Kasım 1917'de kurulan ve kısa bir süre sonra Bolşevikler tarafından ortadan kaldırılan Kırım Ahali Cumhuriyeti'nin Kanuni Esasisinin 18. Maddesinde kadın haklarına şu şekilde değinilmiştir.

"XVIII- Kurultay, müsavat-ı beşer esasını kabul ettiğinden, kadınların da erkeklerle beraber aynı hukuka malik olduklarını tasdik eder ve bu müsavat esası üzerine bir kanun yapılmasinı Meclis-i Mebusan'a havale eder."21.

Kırım Mecmuası'nın içeriğinin genel Türk Tarihi açısından kullanılan birinci el kaynaklar açısından da önemi bulunmaktadır. Mecmuadaki konuların daha iyi anlaşılması için fotoğraf, resim ve harita gibi birinci el görsel kaynaklara yer verilmiştir. Örneğin; Çelebi Cihan, ${ }^{22}$ Cafer Seyydahmet, ${ }^{23}$ Bekir Sıtkı Efendi, ${ }^{24}$ Seyyid Celil Hattatof ${ }^{25}$ gibi birçok Kırımlı ünlünün fotoğrafları dergide bulunmaktadır. Keza, Kırım Hanlarının bastırdığı iki sikkenin, ${ }^{26}$

19 Ömer Seyfettin, “Büyük Türklüğü Parçalayanlar Kimlerdir?”, Kırım Mecmuası, nr.1, İstanbul 2 mayıs 1334 , s. $3-5$

20 O. K. Hatif, “Rus İnkılabında Türk-Tatar Kadınlığı”, Kırım Mecmuası , nr. 6, İstanbul 11 Temmuz 1334, s. 109112; Ziynetullah Nuşirevan, "Şeriat Esasları ve Kadınlık Meseleleri-I-II", Kırım Mecmuası , nr. 10, İstanbul 5 Eylül 1334, s. 181-182; Kırım Mecmuası, nr. 11, İstanbul 26 Eylül 1334, s. 201-204; Fahreddin Tonguç, "Kırım Kadınlığg-I-II", Kırım Mecmuası, nr. 3, İstanbul 30 Mayıs 1334, s. 54-56; Kırım Mecmuası , nr. 5, İstanbul 27 Haziran 1334, s. 96-97; Aynülhayat, "Rusya Kadınlarının Hayat ve Faaliyet-i İctimaiyyesi”, Kırım Mecmuası, nr. 4, İstanbul 13 Haziran 1334, s. 65-67.

21 İmzasız, "Kurultay Kanun-i Esasisi ve Hükümet-i Milliye”, Kırım Mecmuası , nr.2, İstanbul 16 mayıs 1334, s.2123

22 Çelebi Cihan Efendi resmi için bkz. Kırım Mecmuası, nr.1, s.12

23 Cafer Seydahmet resmi için bkz Kırım Mecmuası, nr.1, s.10

24 Bekir Sıtkı Efendi için bkz Kırım Mecmuası, nr.2, mündercerat kısmı

25 Seyyid Celil Hattatof resmi için bkz. Kırım Mecmuası, nr.7, s.131

26 Kırım parası için bkz. Kırım Mecmuası, nr. 3, s.51 
Kırım Hanlarının oturduğu Bahçesaray'daki Han Saray'ın,, ${ }^{27}$ Kırım gök bayrağının asıldığı ilk geminin de fotoğrafları vardır. Bunların yanında Osmanlı padişahı Sultan VI. Mehmet $\mathrm{Han}^{28}$, Afganistan Emiri İnâyetullâh Han, ${ }^{29}$ Kırım Hükümeti Milliyesi'nin İstanbul temsilcisi Hüseyin Sabri Bey ${ }^{30}$, Mecmuanın Müdürü Süleyman Sudi Bey ${ }^{31}$, II. Bütün Rusya Müslümanları Kongresi katılımcıları ${ }^{32}$, Kırım Milli İcra Komitesi üyeleri ${ }^{33}$ ve Kazan ve Kırım murahhaslarının dersaadette çekildikleri resimleri de yer almaktadır. Ayrıca mecmuada Ural-İdil İslam Cumhuriyeti'nin ${ }^{34}$ ve Ukrayna Hükümetinin sınırlarını ${ }^{35}$ gösteren haritada yer almaktadır.

\section{Sonuç}

Çalışmada yer verilen Kırım Mecmuası gerek işlenen konular gerekse mecmuada aktif olarak yer alan tarihi şahsiyetler ve de çıkarıldığı dönemin tarihi, siyasi, kültürel atmosferini yansıtması dolayıyla Genel Türk Tarihi alanında önemli bir kaynak hüviyetindedir. Mecmua, her ne kadarda uzunca bir dönem yayın hayatını sürdürememiş olsa da sahip olduğu değerli içerik nedeniyle diğer birçok mecmua çalışması gibi önemli bir yere sahiptir. Bu çalışmada, Genel Türk Tarihi araştırmacılarının dergi içeriğine dikkatlerinin çekilmesi amaçlanmış ve bu amaçla da derginin önemi ve içeriği hakkında bilgi verilmeye çalışılmıştır. Özelliklede Rusya'nın 16 Mart 2014'te yasa dıșı referandumu ileri sürerek ilhakı ile tekrar gündeme gelen ve sıcaklığını koruyan Kırım meselesinden dolayı da yaklaşık bir asır önce çıkan bu dergide yer alan konuların önem arz ettiği düşünülmektedir. Yüz yıl önce Kırım'ın tekrar bağımsızlığını kazanması için İsmail Gaspıralı'nın “Dilde, fikirde ve İşte birlik” ülküsü doğrultusunda yayınlanan Kırım Mecmuası bütün bunların yanında özellikle Türk dünyası ile ilgili ilmi, edebi, dini ve içtimai konuları irdelemesi bakımından örnek teşkil etmesi açısından da dikkat çekicidir. Bilhassa 16 Mart 2014'de Kırım Tatar Meclisinin boykot kararı aldığı referandumun hemen ardından 5 gün sonra düzenlenen törenle uluslararası kamuoyunun tüm tepkisine rağmen tek taraflı olarak Rusya'ya bağlanan günümüz Kırım’ında Türk varlığının en önemli göstergelerinden biri Kırım Mecmuası'dır (Bkz. Ek:1).

27 Han saray resmi için bkz. Kırım Mecmuası, nr. 1, s.11

28 Sultan VI.Mehmet Han resmi için bkz Kırım Mecmuası, nr.6, s.109

29 Afganistan Emiri İnâyetûllah Han resmi için bkz. Kırım Mecmuası, nr.20, s.352

30 Hüseyin Sabri Bey’in resmi için bkz Kırım Mecmuası, nr.8, s.149

31 Süleyman Sudi Bey’in resmi için bkz Kırım Mecmuası, nr.99, s.169

32 II.Rusya Müslümanları Kongresi katılımcılarının resmi için bkz. Kırım Mecmuası, nr.4, s.70

33 Kırım Milli İcra Komitesi üyeleri için bkz. Kırım Mecmuası, nr.13, s.241

34 Ural-İdil İslam Cumhuriyeti haritası için bkz Kırım Mecmuası, nr.6, s.112

35 Ukrayna Hükümeti haritası için Bkz Kırım Mecmuası, nr.2, s.30 


\section{KAYNAKÇA ${ }^{36^{*}}$}

AYNÜLHAYAT, “Rusya Kadınlarının Hayat ve Faaliyet-i İctimaiyyesi”, Kırım Mecmuası, nr. 4, İstanbul 13 Haziran 1334 1917.

AZİZ,Ömer, “Türklük mü Tatarlık mı?” Kırım Mecmuası, nr. 13, İstanbul 1324 Teşrinievvel

BALA, Mirza, "Kırım", İslam Ansiklopedisi, VI.

BEKTÖRE,Şevki,"Kırım İçün", Kırım Mecmuası, nr. 1, İstanbul 2 Mayıs 1334/1918

ÇAKAN, Varis, Orta Asya Türk Tarihinin Kaynakları, Binyıl Yayınları, Ankara 2009.

DOĞAN, Ahmet, Kırım Mecmuası 1-23 sayılar (Fihrist ve Metinler), Basılmamış Yüksek Lisans Tezi, Atatürk Üniversitesi Sosyal Bilimler Enstitüsü, Erzurum, 2000.

DEVLET, Nadir , 1917 Ekim Ihtilali ve Türk-Tatar Meclisi (İç Rusya ve Sibirya Müslüman Türk Tatarlarının Millet Meclisi-1917-1919), İstanbul 1998 1982.

DEVLETŞìiN, Tamurbek, “Ceditçilik (Yenileşmek)”, Emel, nr. 132 (Eylül-Ekim), Ankara

GEORGEON, François, Türk Milliyetçiliğinin Kökenleri: Yusuf Akçura (1876-1935), çvr. Alev Er, İstanbul 1999.

GÖMEÇ, Saadettin, İslam Öncesi Türk Tarihinin Kaynakları Üzerine, Ankara Üniversitesi Dil ve Tarih-Coğrafya Fakültesi Tarih Bölümü Tarih Araştırmaları Dergisi, Cilt. 20, Sayı 31, ss. 51-92

HABLEMİTOĞLU, Necip, Çarlık Rusyasında Türk Kongreleri (1905-1917), Ankara 1997.

HABLEMITOĞLU, Şengül-HABLEMITOĞLU, Necip, Şefika Gaspıralı ve Rusya'da Türk Kadın Hareketi (1893-1920), Ankara 1998.

HATİF, O[sman] K[emal], Gök Bayrak Altında Millî Faâliyet, İstanbul 1334 (1918).

O. K. Hatif, “Çelebi Cihan Efendi Merhum”, Kırım Mecmuası, nr. 1, İstanbul 2 Mayıs $1334 / 1918$

O. K. Hatif, “Rus İnkılabında Türk-Tatar Kadınlı̆̆ı”, Kırım Mecmuası, nr. 6, İstanbul 11 Temmuz 1334

HAŞiM, Galatasaray Sultanisi Muallimi Nüzhet ,"Bugünkü Türkçülükte Lisan Telakkisi",

36*Kırım Mecmuası'ndan alınan makale veya sair yazılar, eklerde fihrist bölümünde yer aldığı için tamamı kaynakçaya alınmamıştır. 
Kırım Mecmuası, nr.4, İstanbul, 13 Haziran 1334/1918,

HÜSAMETTİN, Muallim, "Kırımda Lisan-ı Resmi Meselesi”, Kırım Mecmuası, nr.9, İstanbul 22Ağustos 1334/1918

ILGAR, İhsan, Rusya'da Birinci Müslüman Kongresi, İstanbul 1998.

İNALCIK, Halil, “Osmanlı-Rus Rekabetinin Menşei ve Don-Volga Kanalı Teșebbüsü”, Belleten, nr. 46, Ankara 1948.

İNALCIK, Halil, “Türklük ve Tatarlık: Osmanlı Devleti ve Kırım Hanlığı”, Yeni Türkiye Dergisi (Türk Dünyası Özel Sayısı), nr. 16, Ankara Temmuz 1997.

KEMAL,Saffeti, "Dilde,fikirde,işde birlik", Kırım Mecmuası, nr.3, İstanbul 30 Mayıs $1334 / 1918$

KEMAL, Çubukçuzade Safveti “Türklük-Tatarlık I”, Kırım Mecmuası, nr. 2, İstanbul 16 Mayıs 1334

KEMAL, Çubukçuzade Safveti “Türklük-Tatarlık II”, Kırım Mecmuası, nr. 5, İstanbul 27 Haziran 1334.

KEMAL, Çubukçuzade Safveti “Türklük-Tatarlık II”, Kırım Mecmuası, nr. 7, İstanbul 25 Temmuz 1334.

KIRIMAL, Edige, "Kırım Türklerinin Millî Mücadelesi”, Emel, nr. 134 (Ocak-Şubat), Ankara 1983.

KIRIMER, Cafer Seydahmet, Bazı Hatıralar, Emel Türk Kültürünü Araştırma ve Tanıtma Vakfı Yayınları, İstanbul, 1993.

KIRIMLI, Hakan, Kırım Tatarlarında Milli Kimlik ve Milli Hareketler (1905-1916), TTK Yay. Ankara, 1996.

KIRIMLI, Ahmet İhsan, “Kırım”, Yeni Türkiye Dergisi (Türk Dünyası Özel Sayısı), nr. 16, Ankara Temmuz 1997.

KURAT, Akdes Nimet, Türkiye ve Rusya, Ankara 1990.

MARAŞ, İbrahim, “İsmail Gaspıralının Bilinmeyen Bir Risalesi: Mektep ve Usul-i Cedit Nedir?", Emel, nr. 219 (Mart-Nisan), Ankara 1997.

MESUD, Mahmut, “Milliyet Prensipleri Hakiki Müslümanlara Kabil-i Tatbik midir?”, Kırım Mecmuası, nr. 16, İstanbul 12 Kanunievvel 1334

NUŞİREVAN, Ziynetullah, "Şeriat Esasları ve Kadınlık Meseleleri”, Kırım Mecmuası, nr. 10, İstanbul 5 Eylül 1334, 
ORTAY, Selim, Kırım İstiklâl Davâsı, Köstence 1939 (Arap harfli Türkçe).

ÖZTÜRK,Ayhan, "Kırım Muhtar Türk Cumhuriyeti”, Türk Yurdu Dergisi (Türk Dünyası Özel Sayısı), nr. 14, Ankara Eylül 1994.

SABİT, Halim “Türk Birliği Yolunda”,Kırım Mecmuası, nr. 2, İstanbul 16 Mayıs 1334,

SAYDAM, Abdullah, Kırım ve Kafkas Göçleri (1856-1876), Ankara 1997.

SEYFETTINN, Ömer, "Büyük Türklüğü Parçalayanlar Kimlerdir?”, Kırım Mecmuası, nr. 1, İstanbul 2 Mayıs 1334,

TAHİR, Mahmut, "Gaspıralı İsmail Bey ve Ganibay Hüseyinov", Emel, nr. 148 (MayısHaziran), Ankara 1985.

TAŞAĞIL, Ahmet, “Genel Türk Tarihi”, Tarih İçin Metodoloji, (Ed. A. Şimşek), Pegem Akademi Yayınları, Ankara, 2016.

TONGUÇ, Fahreddin “Kırım Kadınlığı”, Kırım Mecmuası, nr. 3, İstanbul 30 Mayıs 1334

ÜLKÜSAL, Müstecip, Dobruca ve Türkler, Ankara. 1987.

ÜLKÜSAL, Müstecip, Kırım Türk-Tatarları, Türk Kültürünü Araştırmaları Enstitüsü Yayınları, Ankara, 1980. 


\section{EKLER}

\section{Kırım Mecmuası'nın Fihristi}

\begin{tabular}{|c|c|}
\hline 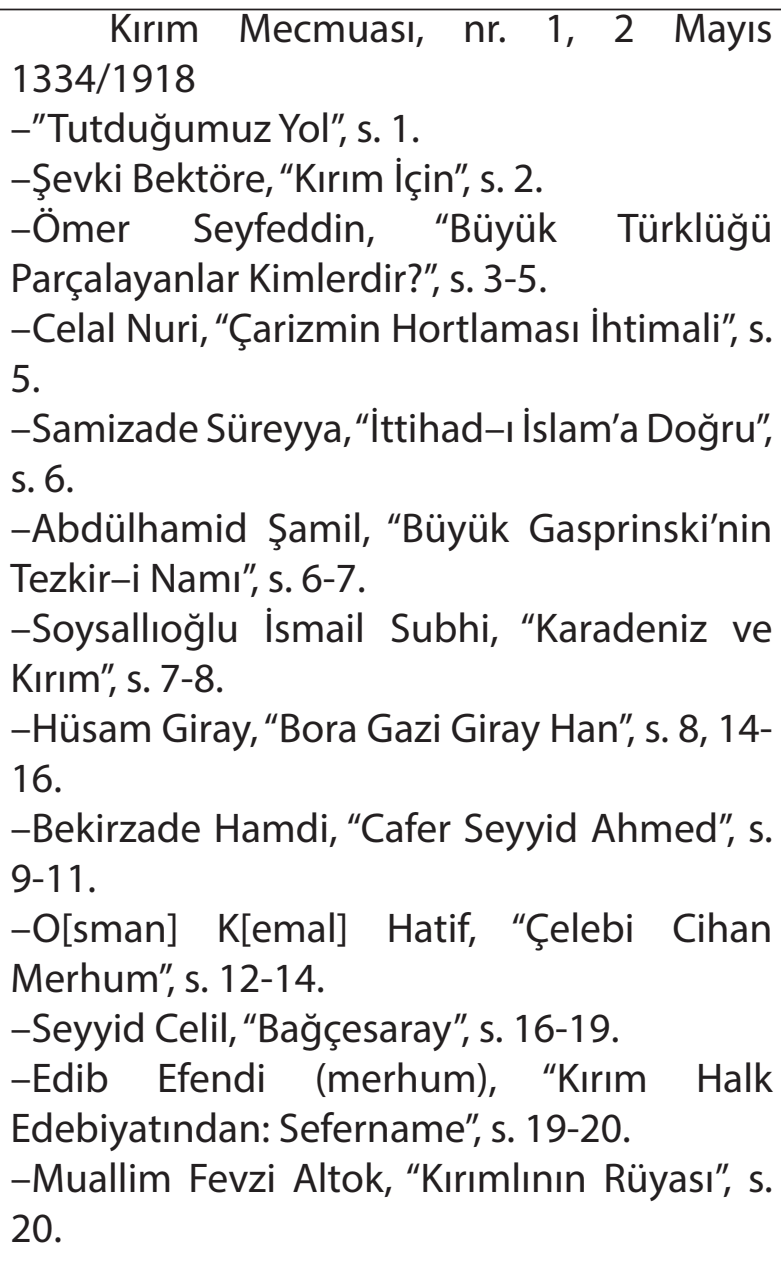 & 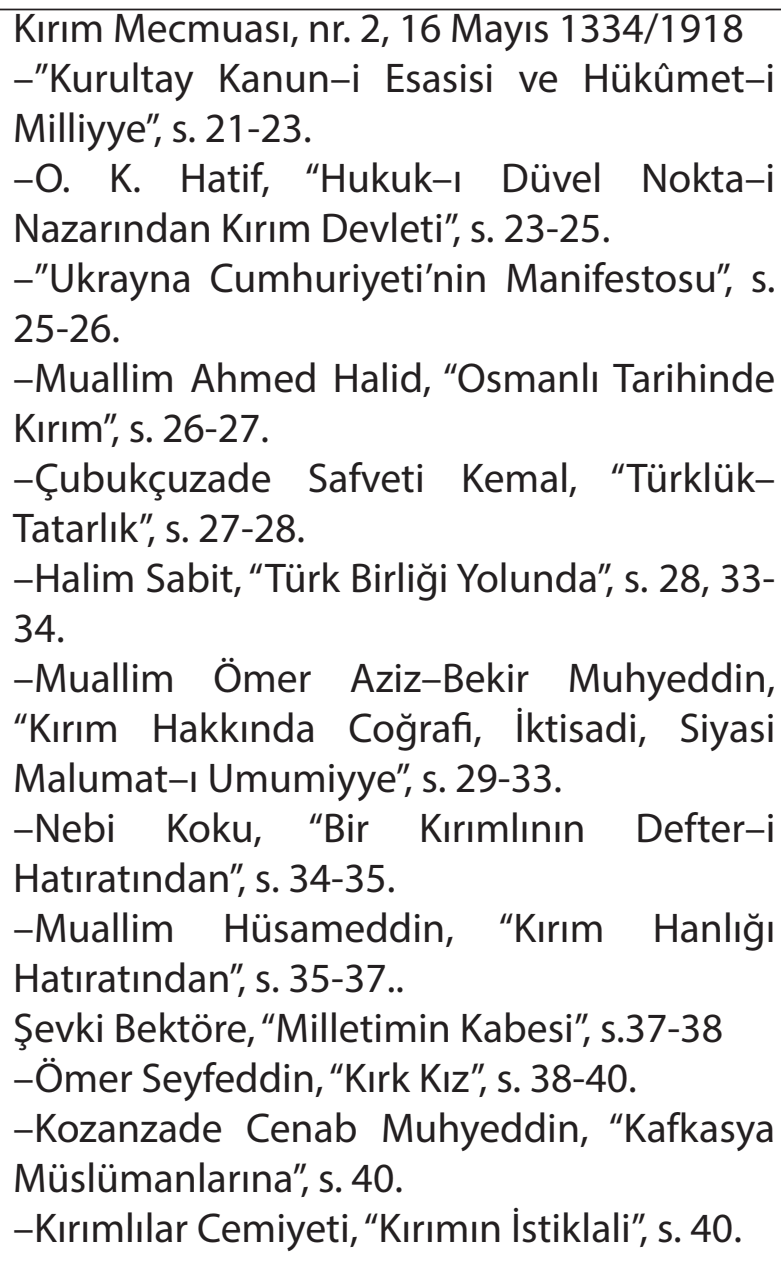 \\
\hline
\end{tabular}


Kırım Mecmuası, nr. 3, 30 Mayıs 1334/1918

-"Kırımda Bir Resm-i Geçid", s. 41-43.

-Safveti Kemal, "Dilde, Fikirde, İşde Birlik", s. 43-44.

- Cafer Seyyid Ahmed-Hamdullah Subhi, "Türk Ocağında", s. 44-45.

-Şevki Bektöre, “Dalgalara",s.45

-Ş. Haytagil, "Kırım Günleri”, s. 46..

-Ali Enver, "Kırım için",s.46

-O.Faik, "Sultan'ın ölümü", s.46-47

-Cenap Muhiddin, "Tahmis", s.47-48

-Fevzi Altok, "Kırım Kurultayına”, s. 48.

-Cemile Nuşirevan, "Kırımın Hicranı", s. 48, 53-54.

-Abdülgaffar, "Kırıma Bir Nazır", s. 49-53.

-Şevki Bektöre, "Güzel Bayrak",s.49

-Fahreddin Tonguç, "Kırım Kadınlığı", s. 54-

56.

-Hüsam Giray, "Rezmi Bahadır Giray Han", s. 56-58.

-Ayaz İshaki, "Bir Turanlının Defter-i Hatıratından", s. 58-60.

Kırım Mecmuası, nr. 5, 27 Haziran 1334/1918

-O. K. Hatif, "Kırımda Nüfus Ekseriyeti", s. 81-

83.

-Abdülgaffar, "Kırım Gençleri Hakkında Bazı

Malumat", s. 83-84.

-O. K. Hatif, "Rusya Müslümanları-I”, s. 85-87.

-Safveti Kemal, "Türklük-Tatarlık”, s. 88.

-Fevzi Altok, "Kırım Gençliği ve Rus İnhilali", s. 88, 92-94.

-Hüseyin Badaninski, "Kırım İslam Sanayi-i Nefisesi Tarihinden", s. 89-9

-Arif Dündar, "Garip Bülbül", s.94

-Çobanoğlu Bekir Bav Bek, "Togan Til", s.9495

-Hüseyin Cahid, "Kırımın Daveti”, s. 95-96

-Numan Bay Börü, "Açu”, s.96

-Fahreddin Tonguç, "Kırım Kadınlığı", s. 9697.

-Ayaz İshaki, "Bir Turanlının Defter-i Hatıratından: Ejderhandan Batuma Giderken", s. 98-99.

-Seyyid Celil Şem'i, "İctimai Hastalıklarımız", s. 99-100.
Kırım Mecmuası, nr. 4, 13 Haziran 1334/1918

-"Bağçesaraydaki Milli Müesseseler", s. 6265.

-Aynülhayat, "Rusya Kadınlarının Hayat ve Faaliyet-i İctimaiyyesi", s. 65-67.

-M. Nuri, "İslam Giray Han", s. 67-68, 73.

-Safveti Kemal, "Kırım Düğünleri", s. 69-73

-Mehmet Niyazi, "Hep Vatan", s.74

-Şevki Bektöre, "Ey Çatırtav!", s.75

-Galatasaray Sultanisi Muallimi Nüzhet Haşim, "Bugünkü Türkçülükte Lisan Telakkisi”, s. 75-76.

-Bahaeddin Tevfik, "Bir Kırımlının Arzusu", s. 77-79.

-Ömer İrfan, "Kırımlı Gençlere-İnkılab ve İhtiras", s. 79.

-Ayaz İshaki, "Bir Turanlının Defter-i Hatıratından: Ejderhandan Batuma Giderken", s. 80.

Kırım Mecmuası, nr. 6, 11 Temmuz 1334/1918 -Kırım Mecmuası, "Bayram”, s. 101.

-Yakub Kemal, "Şarkda Büyük Bir Millet", s. 101-102.

-Yusuf Muzaffer, "Rusya Müslümanları Hayatından", s. 102-103.

-Fuad Viting, "Kırım Hakkında Mütalaat", s. 103-1

-Ahmed Cevad, "Sergüzeşt", s. 106-107.

-Seyyid Celil Şem'i, "Kırım İctimaiyatından", s. 107-108.

-O[sman] Akçokraklı, "Kırımda Bayrak Meselesi", s. 108, 112-114.

-O. K. Hatif, "Rus İnkılabında Türk-Tatar Kadınlığı", s. 109-112.

-Muallim Hüsameddin, "Kırım Tarihinden", s. 114-116.

-Manisa Sultanisi Muallimi M. Nuri, "On Senelik Bir Hayat", s. 116-117.

-Ayaz İshaki, "Şimaldeki Kardeşlerimiz", s. 118-119.

-Ayaz İshaki, "Bir Turanlının Defter-i Hatıratından: Ejderhandan Batuma Giderken", s. 120. 
Kırım Mecmuası, nr. 7, 25 Temmuz 1334/1918

Kırım Mecmuası, nr. 8, 8 Ağustos 1334/1918 -Çobanzade Bekir Sıdkı, "Macar Kardaşlar", s. 121-125.

-Doktor İgnats Kunoş, "Tuna Boyu Tatarları", s. 141-143.

-Safveti Kemal, "Türklük-Tatarlık”, s. 125-126.

-Kadızade Arif Dündar, "Genç Kırımlıya", s.126-127

-"Kırımlılar Cemiyet-i Hayriyyesi", s. 143-144.

-"Birinci Müslüman Kolordusunun Tarihi", s. 144-145.

-Çobanoğlu Bekir Bav Bek, "Kaval

Sesleri",s.127

-Timurcan,"Yurduma", si127

-Kırımlıoğlu Yunus, "Sevimli Kırım", s.127

-Raşid Aşki Çorabatur, "Tahassür", s. 128.

-Hüsam Giray, "Kırımın Şanlı Tarihinden: $\mathrm{HaCı}$

Selim Giray Han", s. 129-134.

-Aziz Temuçin, "İdeal Uğrunda”, s. 134-136.

-Fevzi Altok, "Kırımlıların Kırımda ve

Anadoluda Çiftçiliği", s. 136-137.

-Aynülhayat, "Bir Tahtla Bir Tabut Arasında",

s. 137-138.

-Habil Adem, "Rus Usul-i Temsili”, s. 138-140.

Kırım Mecmuası, nr. 9, 22 Ağustos 1334/1918

-O. K. Hatif, "Kırımda Bolşevik İstilası

Tarihinden", s. 161-164.

-Hüsam Giray, "Kırımın İstila ve İşgali ve Muhaceret Meselesi", s. 164-165.

-Seyyid Celil, "Hakimiyet ve Devlet", s. 166167.

-Muallim Hüsameddin, "Kırımda Lisan-ı

Resmi Meselesi", 167.

-H.Cahit, "Şevki Bektöreye", s.167-168

-Haluk Nihat, "Büyük Mefkure Şehitlerine",

S.168

-Raşid Aşki Çorabatur, "İthaf", s. 168, 170.

-"Hasan Sabri Bek Ayvazof", s. 169-170.

-Hayrünnas Mahir, "Makedonya

Siperlerinde", s. 171-172.

-M. Sami, "Milletlerin İstiklali ve Jimnastik", s.

145-147.

-Çelebi Cihan, "And Etkemen", s. 147.

-Şevki Bektöre, "Sılam", s.147-148

-Hüseyin Cahit, "Tan Yıldızı", s.148

-H...., "Güzel Kırımga" s.148

-Reşid İzzeddin, "Fen ve Edebiyat", s. 149152.

-O.E. "Sevgili Kırım İçin", s. 152.

-Zileyülük, “ildaşlarıma”, s. 152.

-Şevki Bektöre, "Kırım İçin", s.152

-Hüsam Giray, "Kırımda Maarif Meselesi", s.

153-154.

-Habil Adem, "Rus Usul-i Temsili", s. 154-160.

Kırım Mecmuası, nr. 10, 5 Eylül 1334/1918

-Ziynetullah Nuşirevan, "Şeriat Esasları ve Kadınlık Meseleleri", s. 181-182.

-O. K. Hatif, "Kırımda Bolşevik İstilası Tarihinden", s. 183-18

-Şevki Bektöre, "Han Cami Karşısında Yaş Yürekler", s.186

-Bey Eriş, "Bir Babanın Tasası”, s.186

-Fahreddin Tonguç, "Kırımda İslam Nüfusunun Artması", s. 187-188.

-Fevzi Altok, "Kırım Medreseleri", s. 188-189.

-Faik, "Şahin Giray", s. 189-196.

-Habil Adem, "Rus Usul-i Temsili", s. 196-199.

-"Tatar Cemiyet-i Hayriyyesi ve Tavzih-i

Hakikat", s. 199-200.

-"Macaristan'a Talebe İzamı", s. 200.

-Habil Adem, "Rus Usul-i Temsili", s. 178-179.

-"Tatar Cemiyet-i Hayriyyesinden Varid

Olmuşdur: Tavzih-i Hakikat", s. 179-180. 


\begin{tabular}{|c|c|}
\hline Im Mecmuası, nr. 11, 26 Eylül 1334/1918 & 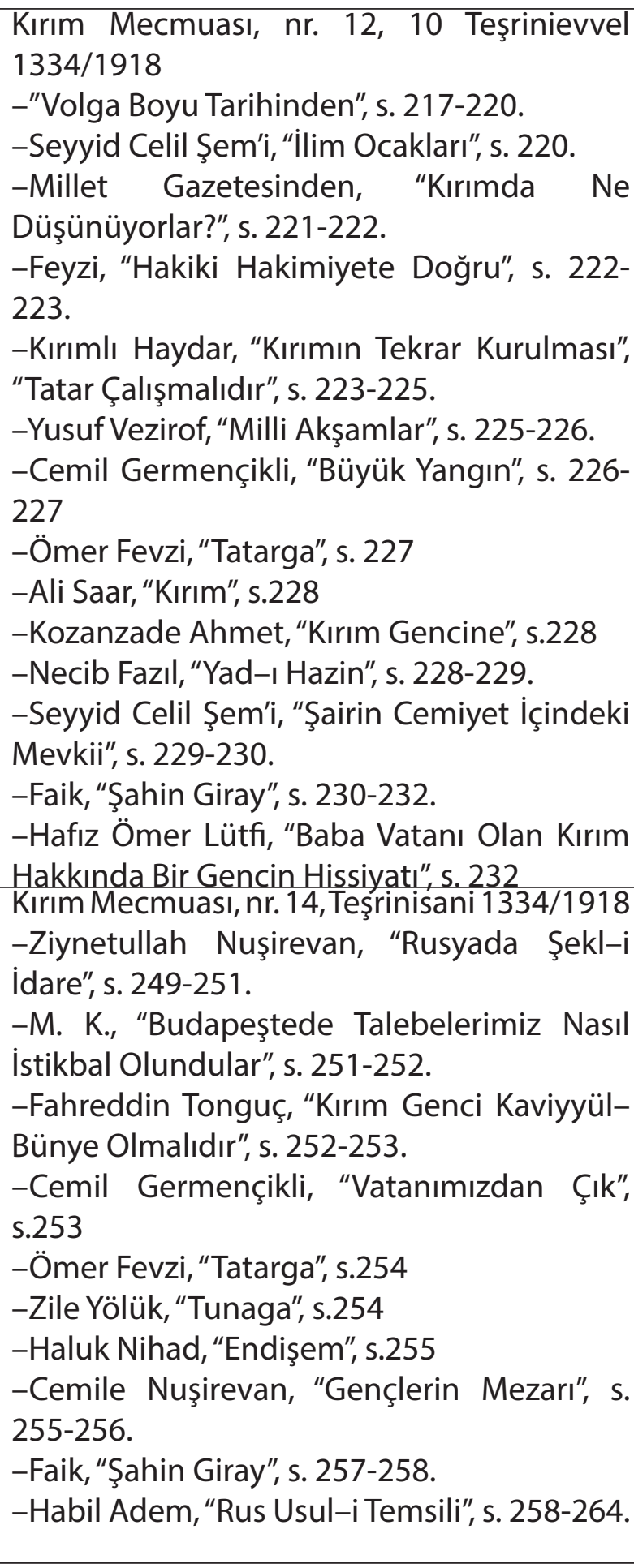 \\
\hline
\end{tabular}


Kırım Mecmuası, nr. 15, 21 Teşrinisani $1334 / 1918$

-Ziynetullah Nuşirevan, "Rusyada Şekl-i İdare", s. 265-267.

-E. M., "Bir Heyet-i İctimaiyyenin Teali ve Tedennisi Esbabı", s. 267-268.

-Muallim Hüsameddin, "Bolşeviklerle Hesab Zamanı", s. 268-269.

-Haluk Nihad, "Harabelerde", s.269

-M. Fikret, "Gün Doğuşu”, s. 270.

-Raşid Aşki Corabatur, "Gazete”, s. 270-271.

-Fahreddin Tonguç, "Vilsonun Prensipleri, Tatar Milleti", s. 272-273.

-Habil Adem, "Rus Usul-i Temsili", s. 273-276.

-E. Rıza, “Mazi Hatıralarından”, s. 276-280.
Kırım Mecmuası, nr. 16, 12 Kanunievvel 1334/1918

-Ziynetullah Nuşirevan, "Kafkasya ve TürkTatar Akvamı", s. 281-282.

-Vedad Örfi,"Kırım Meseleleri:Ondokuzuncu Asırda; Birinci Kısım: Rusya", s. 282-284.

-Mahmud Mesud, "Milliyet Prensipleri Hakiki Müslümanlara Kabil-i Tatbik midir?", s. 284-285.

-Zile Yölük, “idil Boyu”, s.285

-Haluk Nihad, "Askerlerimize", s.286

-Mehmed Fahreddin (Tonguç), "Kırım Gençliği Kaviyyül-Bünye Olmalıdır", s. 286287.

-Bursalı Mehmed Tahir, "Idare-i Osmaniyye Zamanında Yetişen Kırım Müellifleri", s. 288292.

-E. Rıza, "Kırımın Mazi Hatıralarından”, s. 292296.

-Kırımlı Abdülhalim Hilmi, "Esad Beğe", s. 296.

Kırım Mecmuası, nr. 17, 4 Kanunisani $1335 / 1919$

-Mehmed Fahreddin (Tonguç), "Mahkûm Milletlerin Yükselmesi", s. 297-298.

-Mahmud Mesud, "Milliyet Prensipleri Hakiki Müslümanlara Kabil-i Tatbik midir?", s. 298-299.

-Sudi, "Gök Bayrak", s. 300.

-Haluk Nihad, "Kış...", s.300

-Zile Yölük, “Dünya Ucmah Bulanda”, s.300

-Nüzhet, "Musikimiz", s. 301-302.

-Bursalı Mehmed Tahir, "Idare-i Osmaniyye Zamanında Yetişen Kırım Müellifleri", s. 302309.

-E. Rıza, "Kırımın Mazi Hatıralarından", s. 309312.

-Mehmed Fahreddin (Tonguç), "Abdurrahman Beğ", s. 312.
Kırım Mecmuası, nr. 18, 22 Kanunisani $1335 / 1919$

-Safveti Kemal, "Kırımın İstiklali Milletin Hakkı", s. 313-314.

-Mehmed Fahreddin (Tonguç), "Türkiyede Kırım Muhacirleri", s. 314-315.

-Mahmud Mesud, "Osmanlı Hakanları ve Kırım Hanları", s. 316-317.

-Sudi, "Kurtulacak Kırıma”, s.317-318

-Osman Ruhi, "Meriç'in Geceleri", s.318

-Raşid Aşki, "Korkulu Rüyalar", s. 319-320.

-Mahmud Mesud, "Akvam-ı İslamiyye", s. 320-322.

-S. Sudi, "Rumelinin Makedonya Kısmında Düğün Âdetleri", s. 322-325.

-Muallim Hüsameddin, "Küçük

Abdurrahman Beğ İçin", s. 325-326.

-Mehmed Akif, "Köy Hocası", s. 327-328. 
Kırım Mecmuası, nr. 19, 13 Şubat 1335/1919 -Azmi, "Istanbul-Türklük", s. 329-330 ${ }^{1^{*}}$.

-Mahmud Mesud, "Tatar ve Türk", s. 331-332.

-H.T., "Ana", s.334

-Zile Yölük, "Sığırcık", s.335

-Ziynetullah Nuşirevan, "Kırım Müellifleri Münasebetiyle", s. 333-334.

-C[emile] N[uşirevan], "Mukaddes Rüya", s. 335-336.

-C. Ülker, "Emel Yolunda", s. 336-337.

-Safveti Kemal, "Kırımın İstikbali", s. 337-338.

-Mehmed Fahreddin (Tonguç), "Karilerimize”,

s. 338-340.

-Mahmud Mesud, "Akvam-ı İslamiyye", s.

340-342.

-S. Sudi, "Rumelinin Makedonya Kısmında

Düğün Âdetleri", s. 342-344.

Kırım Mecmuası, nr. 21, 27 Mart 1335/1919

$-"$ ", s. $361-363^{2^{*}}$.

-Nureddin Agat, "Kırımlılar Arasında Sınıf Kavgaları", s. 363-365.

-Mahmud Mesud, "Akvam-ı İslamiyyeden

Arablar", s. 365-366.

-Mahmud Mesud, "Tatar ve Türk", s. 367.

-Raşit Aşki,"Kırım İçin", s.367-368

-E.Fahri, "Kış Gecesi", s.368

-Osman Cudi, “Tereze Tübinde”, s. 368-370.

-E. Şükrü, “Rüya”, s. 370-371.

-Dânâ, "Tulu", s. 371-372.

-E. Fahri, "Bir Hatıra”, s. 372-373.

-Mahmud Mesud, "Kaşgar Kıt'a-i İslamiyyesi ve Yakub Han", s. 374-375.

-"Yeni Afgan Emiri", s. 375.

Kırım Mecmuası, nr. 23, 10 Mayıs 1335/1919

-Mehmed Fahreddin (Tonguç), "Üstad-ı

Bînazir Süleyman Nazif Beğefendi

Hazretlerine", s. 385-387.

-Çatırtavlı, "Tatarının Hali", s. 387.

-"Dobruca Müslümanları", s. 388.

-Safveti Kemal, "Bağçesaray-II", s. 388-389.

-O. K. Hatif, "Zincirli Medresesi", s. 389-390.

-Raşid Aşki, "Ne Yapsak Nafile, Eli Tutan Yok",

s. 390-391.

-Dobrucalı Abdulhalim Hadi, "Tuna", s.391-

392

_"Boray Sık", s. 39
Kırım Mecmuası, nr. 20, 6 Mart 1335/1919

-Nureddin Agat, "Kırımlılar Arasında Sınıf

Kavgaları-I", s. 345-346.

-Mahmud Mesud, "Tatar ve Türk", s. 346-347.

-"Tarihi Mektublar: Temür Han ve Fransa

Kralı Altınc Kalos", s. 347-348.

-Mahmud Mesud, "Şarkda Büyük Bir İslam

Hükümdarının Şehid Edilmesi", s. 348-349.

-Defterdar E. Fahreddin, "Bir Rüya", s. 350351.

-Raşid Aşki (Çorabatur), "Eskişehir", s. 351353.

-Mahmud Mesud, "Akvam-ı İslamiyye", s. 353-355.

-Mahmud Mesud, “Kaşgar Kıt'a-i İslamiyyesi ve Yakub Han", s. 355-358.

-S. Sudi, "Rumeli Düğün Âdetleri”, s. 358-360.

Kırım Mecmuası, nr. 22, 24 Nisan 1335/1919

-"Tatar Milleti", s. 377-378.

-Ziynetullah Nuşirevan, "Halk Edebiyatının Ehemmiyeti Hakkında", s. 378-379.

-Zile Yölük, "Muhabbet", s.379-380

-Osman Nuri, "Çehre-i Efal", s.381-382

-Osman Cudi, "Teraze Tevbinde", s.382-383

-Safveti Kemal, “Bağçesaray-I", s. 384. 